\author{
HANXIAO LI
}

\title{
CLOSED MATERAIL PROCEDURE IN CIVIL PROCEEDINGS
}

\author{
LAWS 546 RESEARCH PAPER
}

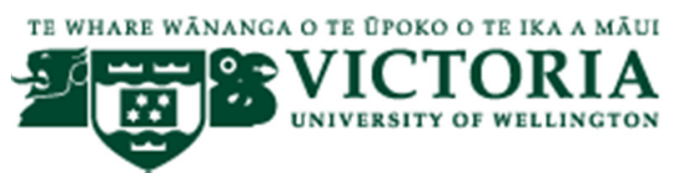

FACULTY OF LAW

OCTOBER 2013 


\section{Table of Contents}

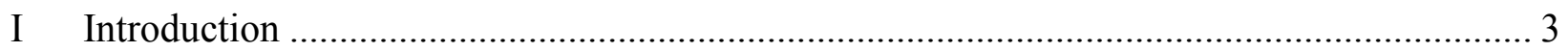

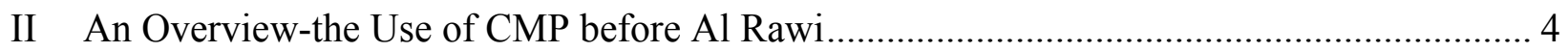

III CMP in the Civil Proceedings-the Courts' Practice ............................................................. 7

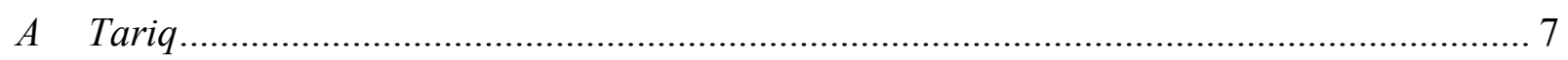

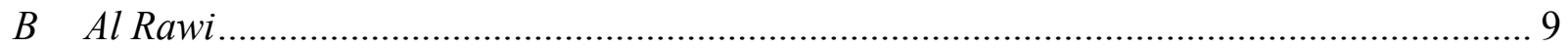

IV CMP in the Civil Proceedings-the Justice and Security Act............................................ 14

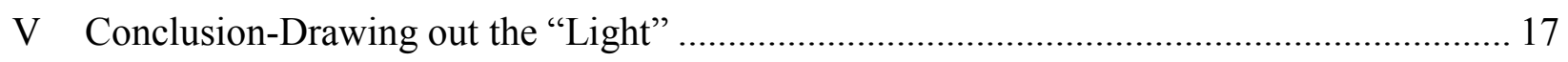

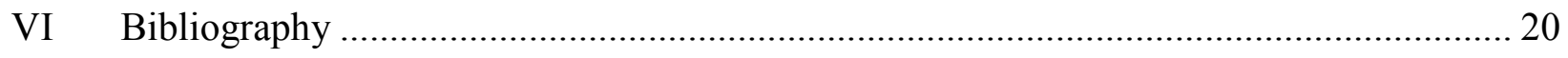

\section{Word Count}

This paper, excluding cover page, table of contents, footnotes and bibliography, comprises approximately 7059 words. 


\section{Introduction}

Items of historical significance of two wars Iraq and Afghanistan Significant Activity, Sigacts, between 0001 January 2004 and 235931 December 2009 extracts from CSV documents from Department of Defence and CDNE database...This is one of the most significant documents of our time removing the fog of war and revealing the true nature of 21 st century asymmetric warfare... ${ }^{1}$

This was part of the message sent along with the documents later known as Iraq and Afghanistan war logs from Chelsea Manning, a United States solider, to the website of WikiLeaks ${ }^{2}$-an international, online, non-profit organisation which publishes secret and sensitive information. The release of the war logs was referred as "the largest leak of classified documents in its history" 3 " and the release of diplomatic cables exposed numerous unguarded comments and revelations regarding critiques and praises about the host countries of various United States embassies; United States intelligence and counterintelligence efforts and other diplomatic actions. These leaks put the United States in great controversy considering its actions in the Iraq and Afghanistan wars and caused quite an embarrassment due to its comments regarding diplomatic actions.

Chelsea Manning was convicted and Julian Assange, the founder of WikiLeaks, is facing potential criminal prosecution, despite being granted political asylum. While WikiLeaks still works as an important role of exposing the "truth" to the public, it imposed great concerns to many of the governments around the world towards their government policies, national security and general reputation. The consequence of WikiLeaks releasing sensitive information about United States government rang the alarm of the importance of governments safeguarding secret information.

The motivation of the United Kingdom government issuing the Justice and Security Act ${ }^{4}$ arguably comes from the concern of exposing sensitive information. The Introduction of the Act reads that the JSA is "to provide for oversight of the Security Service, the Secret Intelligence Service, the Government Communications Headquarters and other activities relating to intelligence or security matters; to make provision about closed material procedure in relation to certain civil proceedings; to prevent the making of certain court orders for the disclosure of sensitive information; and for connected purposes".

\footnotetext{
${ }^{1}$ Denver Nicks Private: Bradley Manning, WikiLeaks, and the Biggest Exposure of Official Secrets in American History (Chicago Review Press, Chicago, 2012) at 137-138.

${ }^{2}$ Wikileaks.org

${ }^{3}$ See $<$ www.bbc.co.uk $>$, a quote from the United States Department of Defence referring the release of Iraq War Logs.

${ }^{4}$ Justice and Security Act 2013 (UK).
} 
This Act, based on the objectives mentioned above, introduced closed material procedure to the civil proceedings, which is regarded as a response to the judgment of $A l$ Rawi, undoubtedly generated huge discussions across boundaries as to the matter of security and liberty; security and due process; security and justice; the Act's in relation to the common law as well as its relationship with Article 6 of the European Convention on Human Rights.

While many of the scholars accused JSA of "turning off the light", this paper would like to direct attention to the Wikileaks incidents and consider the views of both the British government and the promoters of human rights and common law. This paper will first introduce the effect of CMP in the criminal proceedings, and then look at $\mathrm{Al} \mathrm{Rawi}^{6}$ and $\mathrm{Tariq}^{7}$. It will conclude the conflicts when adopting CMP and by interpreting JSA to draw some concerns and the certain "light", as well as some suggestions towards CMP in JSA.

\section{An Overview-the Use of CMP before Al Rawi}

The use of CMP was first adopted in the United Kingdom in the Special Immigration Appeals Commission $\mathrm{Act}^{8}$, which deals with appeals in cases where the Secretary of State for the Home Department (Home Office) exercises statutory powers to deport, or to exclude, someone from the UK on national security grounds, or for other public interest reasons. ${ }^{9}$

It has been said that SIAC was passed in response to the European Court of Human Rights' decision in Chahal v United Kingdon, where the appellant, Karamjit Singh Chahal, who was an Indian national and Sikh separatist, was also a resident in the United Kingdom. Chahal was suspected by the Home Secretary of involvement in terrorist activities. The appellant claimed that if he were to be deported from the United Kingdom, as the Home Secretary wished, he would be tortured by the authorities in India for his non-violent support for Sikh separatism. One of his claims was that although judicial review was available to challenge the Home Secretary's decision in his deportation, the determination of the reason to deport him - his risk to national security - was made by an internal Home Office advisory panel, based on sensitive intelligence material which there was no opportunity for him to challenge for two reasons: first, the sensitive material was precluded from disclosure by public interest immunity; and second, he was not entitled to any form of legal representation before the panel. ${ }^{10}$

\footnotetext{
${ }^{5}$ See for example, Tom Hickman 'Turning out the lights? The Justice and Security Act 2013' (11th June 2013) UK's Constitutional Law Blog <http://ukconstitutionallaw.org > .

${ }^{6}$ Al Rawi v The Security Service and others [2011] UKSC 34. [hereinafter Al Rawi].

${ }^{7}$ Home Office v Tariq [2011] UKSC 34.

${ }^{8}$ Special Immigration Appeals Commission Act 1997 (UK).

${ }^{9}$ See $<$ www.justice.gov.uk $>$.

${ }^{10}$ House of Commons Constitutional Affairs Committee The operation of the Special Immigration Appeals Commission (SIAC) and the use of Special Advocates (22 March 2005) at 19 [46], available at $<$ www.publiction.parliament.uk>.
} 
The ECHR agreed with the appellant's complaints and found the Home Office procedure breached the appellant's rights under Article 5(4) of the ECHR.

Having been influenced by the similar closed proceedings used in Canada, the Court states that ${ }^{11}$ :

The Court recognises the use of confidential material may be unavoidable where national security is at stake. This does not mean, however, that the national authorities can be free from effective control by the domestic courts whenever they choose to assert the national security and terrorism are involved...there are techniques which can be employed which both accommodate legitimate security concerns about the nature and sources of intelligence and yet accord the individual a substantial measure of procedure justice.

The "more effective form of judicial control ${ }^{12}$ " approach of Canada, as described and suggested by the ECtHR was therefore looked at and borrowed by the United Kingdom, as Section 6 of the SICA provided a special advocate system to represent an appellant in cases in which there was non-disclosable sensitive evidence in relation to the immigration decisions of the Home Secretary. The Government described this as " the special advocate is necessary to protect the public interest in not disclosing the sensitive material, while allowing independent scrutiny of that sensitive material by an advocate appointed to represent the interests of the appellant". ${ }^{13}$

Despite the controversy raised by the United Kingdom adopting the special advocate system, and the fact that SIAC still deals with cases involving deportation and deprivation of citizenship, the use of CMP has been extended to control orders cases under the Prevention of Terrorism Act $2005^{14}$ and in financial restrictions proceedings under the Counter-Terrorism Act $2008^{15}$, as well as other instruments concerned with the freezing of terrorist assets ${ }^{16}$.

Special advocates system before migrated to the United Kingdom, was explained by the ECtHR as $^{17}$ :

"a... Judge holds an in camera hearing of all the evidence, at which the applicant is provided with a statement summarising, as far as possible, the case against him or hear and has the right to be represented and to call evidence. The confidentiality of the security material is maintained by requiring such evidence to be examined in the absence

\footnotetext{
${ }^{11}$ Chahal v United Kingdom (1996) 23 EHRR at [130]-[131].

${ }^{12}$ Ibid at [144]. Also see David Jenkins "There and Back Again: The Strange Journey of Special Advocated and Comparative Law Methodology" (2011) 42 Columbia Human Rights Law Review 279 for the comments of the decision by the ECHR in the Chahal case. Available at $<$ www3.law.columbia.edu>

${ }^{13}$ Above 10 at 20.

${ }^{14}$ Prevention of Terrorism Act 2005 (UK).

${ }^{15}$ Counter-Terrorism Act 2008 (UK).

${ }^{16}$ Terrorist Asset-Freezing Act 2010 (UK). See also Ahmed v H M Treasury [2010] UKSC 2, [2010] 2WLR 378.

${ }^{17}$ Above $n 11$ at [141].
} 
of both the applicant and his or her reprehensive. However, in these circumstances, their place is taken by a security-cleared counsel instructed by the court, who cross-examine the witnesses and generally assists the court to test the strength of the State's case.

In practice, however, the special advocates system adopted in the United Kingdom, despite all the vibrant wordings of provisions, does not allow the special advocates to cross-examine witnesses or summon witnesses on the appellants' sides. As Mr Martin Chamberlain, a special advocate, pointed out, the special advocates are simply operating on their own with no other's assistance and do their best to test the closed material, but they cannot show it to the appellants or their solicitors, ${ }^{18}$ nor communicate with them.

This paper will use Secretary of State for the Home Department $v A F^{19}$, a case under the PTA, to draw out the concerns of special advocates system.

The three appellants, AF, AN and AE, are subject to non-derogating control orders involving great restriction of liberty which were made pursuant to Section 2 of the PTA. The issue raised by their claims is whether, in each case, the CMP resulted in the making of the control order satisfied the appellants' right of fair trial guaranteed by Article 6 of the ECHR in conjunction with the Human Rights Act 1998. ${ }^{20}$

Although it said that it is of course open to "parliament to enact legislation that is incompatible with one or more of the Convention rights. The ability to do so is inherent in the constitutional role of a sovereign Parliament ${ }^{21}$ ". While Article 6 required a "core irreducible minimum" of procedural fairness such that " $[\mathrm{t}]$ he controlled person must be given sufficient information about the allegations against him to give effective instructions to the special advocate", the House of Lords held by following a decision in Av United Kingdom ${ }^{22}$, that based on the fact that the disclosed material consisted of only general assertions and that the case against the potential controlee was based solely or primarily on closed material, the CMP taken by the Home Department constituted a breach of article 6 which guaranteed right of fair trial. ${ }^{23}$

Even though the law Lords in $A F$ held unanimously that there should be a core irreducible minimum and that the controlled person should be given enough information which the allegations were made against him/her, the question remained as how to actually measure and

\footnotetext{
${ }^{18}$ Above $\mathrm{n} 10$ at 76.

${ }^{19}$ Secretary of State for the Home Department $v A F$ and other and one other action [2008] EWCA Civ 1148; [2009]UKHL 28

${ }^{20}$ Secretary of State for the Home Department $v$ AF and other and one other action [2009]UKHL 28at [1].

${ }^{21}$ Ibid at [93].

${ }^{22} A$ and other $v$ United Kingdom Application No 3455/05 [GC], judgment of 19 February 2009.

${ }^{23}$ Above $\mathrm{n} 2$ at [59]. For some discussion between their Lordships in $A F$ see also Secretary of State for the Home Department v MB [2007] UKHL 46. See also M Chamberlain "Update on Procedural Fairness in Closed Proceedings" (2009) CJQ 448 at 450; Aileen Kavanagh "Special Advocates, Control Orders and the Right to a Fair Trial" (2010) 73 The Modern Law Review 824.
} 
determine the amount of sensitive information that should be disclosed. There can hardly be a balance of the amount of sensitive evidence the controlled person seeks to be disclosed and the amount of the secret evidence the government actually wants it to be disclosed, let alone how much amount of information can be disclosed above the bottom line.

While the critics of CMP in criminal proceedings have not settled down, two cases that arose under the civil procedure drew the public attention to the fact that the United Kingdom was trying to extend the use of CMP into civil procedures.

\title{
III CMP in the Civil Proceedings-the Courts' Practice
}

\begin{abstract}
Seventeenth century lawyers were fond of quoting the example of Genesis 3.11, in which God, though omniscient, said to Adam "Hast thou eaten of the tree, whereof I commanded thee that thou shouldest not eat?". In such a case, however, there is no cost in compliance with the general rule. God suffered no disadvantage by revealing to Adam what he knew. The same is true in most cases in which there is a failure to disclose material. But when disclosure is contrary to the public interest, it is necessary to think more carefully and ask whether in all the circumstances it would really be unfair not to tell the applicant or accused. There may well be cases in which, from the point of view of reaching the right decision... If that is the case, the procedure may be fair even though a subjective feeling of injustice is unavoidable. ${ }^{24}$
\end{abstract}

\section{A Tariq}

The appellant, Tariq, had worked as an immigration officer since April 2003. His security clearance was withdrawn by the Home Office in December 2003, relating to the arrests of his brother and cousin, who were alleged in connection with the investigation into the suspected terrorist plot to attack multiple trans-Atlantic airline flights in August 2006. Tariq's brother was eventually released without charge while his cousin was convicted of conspiracy to commit murder in September 2008. The Home Office's concern regarding Tariq was that, even though there was no information suggesting Tariq himself had any involvement in the terrorist plot, given his close connection with the persons who were suspected of involvement, he might be vulnerable to outside attempts to have him abuse his position as an immigration officer. ${ }^{25}$

In the employment tribunal proceedings, Tariq claimed that withdrawing his security clearance constituted discrimination on grounds of race and religion while the Home Office said in their

\footnotetext{
${ }^{24}$ Above n 20 at [72]. See also John Ip "Al Rawi, Tariq, and the Future of Closed Material Procedures and Special Advocates" (2012) 75 The Modern Law Review 606.

${ }^{25}$ Ibid at [5].
} 
defence that there was no discrimination in this case, that the decisions taken in relation to Tariq were taken for the purposes of safeguarding national security, and that the order for a CMP made by the Employment Tribunal on the Home Office's application was made justifiable and for the same protective purposes. ${ }^{26}$

Unlike Al Rawi, Tariq had specific statutory authorisation - Section 7 of the Employment Tribunals Act 1996 confers regulation making power upon the Secretary of State and Section 10 specifically authorises regulations providing for CMP. ${ }^{27}$ Moreover, Rule 54 of Schedule 1 of the Employment Tribunals (Constitution and Rules of Procedure) Regulation 2004 provides for the use of CMP, while Rule 8 of Schedule 2 provides for the appointment of special advocates. Based on the fact that the cross-appeal concerned the compliance of the statutory authorising CMP with the ECHR, the appellant argued that the Rule 54 and Rule 8 were contrary to the ECHR. ${ }^{28}$

Therefore, after the Employment Appeal Tribunal and the Court of Appeal dismissed Tariq's challenge to the Employment Tribunal's order for a CMP29, the issue that was put in front of the Supreme Court was not the substantive claim of discrimination but rather it was justifiable for the Employment Tribunal to allow a CMP in this case. In other words, the issue was whether the English Law was in compliance with the ECHR.

The House of Lords held that the use of CMP could be justified under ECHR as it was a means of necessity. As Lord Hope noted ${ }^{30}$,

To be effective security vetting will usually, if not invariably, require to be carried out in secret. Its methods and the sources of information on which it depends be cannot be revealed to the person who is being vetted.

It was recognised that none of the alternatives were satisfactory as CMP, that if CMP was not available, the government would either have to conduct proceedings in the ordinary way, in which case there would be risk damaging the system of security vetting, or the government would have to open itself up to the possibility of unjustified discrimination claims in the future. ${ }^{31}$ The court either has to process the case under CMP, or choose not to hear it at all. ${ }^{32}$

\footnotetext{
${ }^{26}$ Ibid at [2].

${ }^{27}$ Employment Tribunals Act 1996 (UK). See also above n 7 at [9]-[10] and [74].

${ }^{28}$ Above $\mathrm{n} 7$ at [13].

${ }^{29}$ The Home Office v Tariq UKEAT 168/09, [2012]ICR 223; [2010]EWCA CIV 462;[2010]ICR 1034.

${ }^{30}$ Above $n 7$ at [72].

${ }^{31}$ Ibid at [38] per Lord Mance, [79] per Lord Hope.

32 Ibid at [39].
} 
The Supreme Court also held ${ }^{33}$ that the $A F$ principle was inapplicable in this case as the severity in these two cases is different. For example, Lord Hope explained that ${ }^{34}$ :

This is an entirely different case from Secretary of State for the Home Department $v A F$. There the fundamental rights of the individual were being severely restricted by the actions of the executive. Where issues such as that are at stake, the rule of law required that the individual be given sufficient material to enable him to answer the case that is made against him by the state. In this case the individual is not faced with criminal proceedings against him or with severe restrictions on personal liberty. This is a civil claim and the question is whether Mr Tariq is entitled to damages.

It was noted by Lord Kerr in his dissenting opinion that this approach, taken by the majority of the Court, would likely lead to a certain degree of uncertainty - for cases where the liberty of the subject and ordinary control orders were concerned, the $A F$ principle is applicable, therefore a disclosure of secret evidence is needed. Conversely, for cases like Tariq, where the alleged damage was not as severe as criminal charges or deprivation of liberty, a disclosure will not be required. ${ }^{35}$

However, in $A l$ Rawi, another civil claim relevant to CMP, the House of Lords took a different approach to examine the use of CMP in the civil proceedings. The difference might be drawn from the nature of the two cases-that Tariq was concerned about the compliance of statuary authorised CMP with the ECHR, while issues raised in Al Rawi were matter of common law legacy as well as the court's power.

\section{B Al Rawi}

The six claimants ${ }^{36}$ are individuals who were detained at various locations which include the United States detention facility in Guantanamo Bay. The claimants brought their claims together in the Queen's Bench Division of the High Court, alleging false imprisonment, trespass to the person, conspiracy to injure, torture, breach of contract, negligence, misfeasance in public office, and breach of the Human Rights Act 1998 of the defendants, the Security Service, the Secret Intelligence Service, the Foreign and Commonwealth Office, the Home Office and (in a representative capacity) the Attorney General. ${ }^{37}$

\footnotetext{
${ }^{33}$ Lord Kerr held the dissenting opinion in regards to whether the $A F$ principle should be applied in Tariq.

${ }^{34}$ Above $\mathrm{n} 7$ at [81].

${ }^{35}$ Ibid at [133].

${ }^{36}$ Ie Bisher Al Rawi, Jamil El Banna, Richard Belmar, Omar Deghayes, Binyam Mohamed and Marin Mubanga.

${ }^{37}$ Al Rawi and Others $v$ Security Service and Others [2009] EWHC2959 (QB) at [5].
} 
The Government ${ }^{38}$ filed an open defence in which they admitted that the claimants had been transferred and detained, however they denied any liability for the claimants' detention or alleged mistreatment. At a case management hearing, the Government expressed that they were in possession of material which they wished the Court to consider, but which they would be obliged to withhold from disclosure in the public interest.

The Government sought to have the trial held under CMP, whereby disclosure would be made by the Government not to the claimants and their lawyers, but only to the court and to special advocates. To be more specific, the definition of CMP given by the Government is:

A "closed material procedure" means a procedure in which

(a) A party is permitted to

(i) Comply with his obligations for disclosure of documents, and

(ii) Rely on pleadings and/or written evidence and/or oral evidence

Without disclosing such material to other parties if and to the extent that disclosure to them would be contrary to the public interest (such withheld material being known as 'closed material'), and

(b) Disclosure of such closed material is made to special advocates and, where appropriate, the court; and

(c) The court must ensure that such closed material is not disclosed to any other parties or to any other person, save where it is satisfied that such disclosure would not be contrary to the public interest.

For the purpose of this definition, disclosure is contrary to the public interest if it is made contrary to the interests of national security, the international relations of the United Kingdom, the detection and prevention of crime, or in any other circumstances where disclosure is likely to harm the public interest.

The claimants argued that the conventional exercise of Public Interest Immunity (PII) should be adequate enough to apply in this case, which system had the last major change since the decision by the House of Lords in Wiley ${ }^{39}$.

Wiley concerned a claim in respect of documents generated by an investigation into a claim against the police. The House of Lords overruled the authorities and held that the recognition of a new class-based interest immunity required clear and compelling

\footnotetext{
${ }^{38}$ Ie the Defendant in the initial case and the appellants in the subsequent case.

${ }^{39} R v$ Chief Constable of West Midlands, Ex $p$ Wiley [1995] 1 AC 274.
} 
evidence that it was necessary and that nothing should prevent a claim being made for immunity in respect of sensitive material where appropriate. ${ }^{40}$

The basic features of PII, as concluded by the House of Lords in Wiley are: first, it should be considered whether the material is relevant to legal proceedings; second, the government must consider whether disclosing material would impose harm to public interest; finally, it is up to the court to balance whether the public interest in non-disclosure of material outweighs the public interest in disclosure of material, if so, then the relevant minister will sign a certificate to that effect. $^{41}$

Therefore, it is apparent that there are huge differences between CMP and PII. First, under CMP, there is no balancing exercise either by the Government or the court to determine whether the public interest in withholding evidence outweighs the public interest in disclosure. Rather, it relies on the Government to decide what evidence should remain undisclosed, and disclosure of such evidence is made to the special advocates - it can be made to the Court, but only when appropriate. While, under PII, it is the Court's decision, based on the practice of weighing the justice resulting from disclosing and withholding the evidence, which can be best described by Lord Templeman as "a claim to public interest immunity can only be justified if the public interest in preserving the confidentiality of the document outweighs the public interest in securing justice"42.

Second, the evidence which is undisclosed under PII is inadmissible - such evidence can no longer be relied upon by any party, including the court, as evidence. Closed material, however, is still admissible and can be relied on not only by the Government but also by the court.

At this stage, there was no statuary authorisation of court ordering CMP. Lord Hope in the Supreme Court confirmed the view of Court of Appeal-that "it is not open to a court in England and Wales, in the absence of statutory power to order a closed material procedure in relation to the trial of an ordinary civil claim"43 and that the purpose of a court is to develop common law, while introducing CMP to the civil claims of tort would in fact be undermining one of its most fundamental principles, namely, the principle of fair trial, which gives the provision that "under common law, a trial is conducted on the basis that each party and his lawyer sees and hears all the evidence and all the argument seen and heard by the court" ${ }^{4}$.

With the concern of substituting PII with CMP, the House of Lords subsequently discussed CMP in relation to open justice and natural justice, whether CMP should be a further exception as well as whether, it is justifiable for CMP to be a supplementary to PII.

\footnotetext{
${ }^{40}$ Hodge M Malek (ed) Phipson on Evidence (17th ed, Sweet \& Maxwell, London, 2010) at 761.

${ }^{41}$ Above n 26 at 15-16 and also see Adam Tomkins "National Security and the Due Process of Law" (2011) 64 CLP 1 at 1.

${ }^{42}$ Above $\mathrm{n} 26$ at 280.

${ }^{43}$ Al Rawi and Others v Security Service and Others [2010]EWCA Civ 482 at [11].

${ }^{44}$ Ibid at [14].
} 
As noted by Lord Dyson, there are certain essential features of a common law trial inherent to the system of justice-public justice and natural justice ${ }^{45}$ Public justice provides that, subject to certain established and limited exceptions, trials should be conducted and judgments given in public. ${ }^{46}$ Natural justice, on the other hand entitles a party to have a right to know the case against him and the evidence on which it is based. ${ }^{47}$ Under natural justice, a party should have the opportunity to respond to any such evidence and to submission made by the opposition so it may not advance contentions or cite evidence of which it is kept in ignorance. ${ }^{48}$ Also, the parties should be entitled to an opportunity to summon their own witnesses and to cross-examine the opposing witnesses. ${ }^{49}$

According to Lord Dyson, practicing CMP, without a doubt, contradicts the two principles stated above, as exercising CMP can neither enable the parties to have trials open to the public, nor can they know the evidence the other side had against them, let alone respond to the evidence, or summon their own witnesses or cross-examine the opposing witnesses because all the evidence is withheld from the parties under CMP.

The appellants submitted that in certain circumstances, a CMP was necessary to achieve "real justice and a fair trial". ${ }^{50}$ As noted by Lord Kerr, there are two essential arguments according to the appellants. First, a CMP will be easier to apply than a conventional PII exercise. The appellant argued that using CMP in this case can be more efficient than the PII process, as the appellant stated that if applying PII in this case, with up to 250000 potential relevant document of which up to 140000 may involve considerations of national security - which, if the court practices PII procedure, with the employment of 60 lawyers specially for this purpose, would be likely to take up to of three years. ${ }^{51}$ However, this presumption received wide skepticism from the law Lords as to whether an argument from expediency alone can justify such a risk of changing the conventional rule.

The second argument submitted by the appellant is that exercising CMP can result in a fairer outcome..$^{52}$ The appellant argued that CMP can offer an advantage compared to PII, that under which the withheld evidence is inadmissible, either a proceeding has to be continued without the relevant material, or the case becomes untriable - specifically, under the principle of the fair trial, without the disclosed material a fair trial is not possible, thus a trial without the relevant material should not proceed.

\footnotetext{
${ }^{45}$ Above $n 6$ at [10].

${ }^{46}$ Ibid at [11].

${ }^{47}$ Ibid at [12]

${ }^{48}$ Ibid.

${ }^{49}$ Ibid.

${ }^{50}$ Ibid at [8].

${ }^{51}$ Ibid at [79].

${ }^{52}$ Ibid at [91].
} 
This claim, according to Lord Kerr, however, is not logical as failing to disclose such relevant evidence will result in the difficulty of challenging such withheld evidence from the opposing party - as they have no idea what the evidence is. As Lord Kerr observed "evidence which has been insulated from challenge may positively mislead". ${ }^{33}$

As to the discussion of using CMP to substitute or as a supplement to PII, four of the judges in the majority - Lord Dyson, Lord Hope, Lord Brown and Lord Kerr noted that a common law court had no power to order CMP as a substitute or a supplement for PII. ${ }^{54}$ The three dissenting judges - Lord Mance, Lord Clarke and Lady Hale, concluded that there was no power for a court to introduce CMP as a substitute for PII, but they believed that a court had the power to order CMP as a supplement to PII. ${ }^{55}$

In the view of Lord Mance and Lady Hale, a court can order CMP when the undisclosed evidence was in the possession of the defendant and the claimant agreed to CMP to avoid his claim being untriable due to the lack of sufficient evidence, ${ }^{56}$ whereas Lord Clarke took another view, as he agreed both parties should be able to make submissions as to whether CMP should be adopted after the court completes PII procedure. If, a court is persuaded to introduce CMP, then adopting CMP in the civil proceedings should be viewed as a development of the common law. ${ }^{57}$ The idea of development of common law was, of course, disputed by several judges, as this paper introduced above, both the judges in the Court of Appeal and the majority of the judges in the Supreme Court agreed on introducing CMP to the civil proceedings may undermine few of the fundamental principles, which should be considered as contrary to a common law court's duty and the development of the common law.

The mediation with the claimants in the Al Rawi case was finally settled outside the court, while the confidential nature of the mediation kept the agreement within the relevant parties. While the House of Lords were concerned about the role of the court in introducing CMP, the British government responded to the reluctance of the court to order CMP by issuing the Justice and Security Act. If the application of CMP in Tariq was an attempt to introduce CMP in a civil proceeding, then enacting JSA can be regarded as CMP's official acquaintance with the rules of civil proceedings in the common law.

It should be noted that issuing JSA did not actually answer the questions raised in $\mathrm{Al} \mathrm{Rawi} \mathrm{-} \mathrm{that}$ is, CMP's in relation with fair trial. Although it has been said that by Parliament legislating provided the least possibility of challenging CMP on the basis on fair trial, it is attempting, still, to read JSA and draw out some facts to analyse the government's attitude towards the Al Rawi

\footnotetext{
${ }^{53}$ Ibid at [93]. This paper will present an argument as opposed to the judges' finding in the Conclusion.

${ }^{54}$ Ibid at [40]-[49] Lord Dyson, [73] Lord Hope, [81]-[82] Lord Brown and [88] Lord Kerr.

${ }^{55}$ Ibid at [107] and [152].

${ }^{56}$ Ibid at [112]-[121].

${ }^{57}$ Ibid at [159]-[180].
} 
judgment considering the Wiley balance exercise and court's discretion, as well as the future role of CMP in relation to PII.

\section{CMP in the Civil Proceedings-the Justice and Security Act}

Section 6 of JSA gave provisions of declaration permitting CMP in proceedings. Under this section, the court seized of relevant civil proceedings may make a declaration that the proceedings are procedures where a CMP may be made to the court. To make a declaration, in other words, to grant the government the use of CMP, there are two conditions that must be met, which include ${ }^{58}$,

The first condition is that,

(a)a party to the proceedings would be required to disclose sensitive material in the course of the proceedings to another person (whether or not another party to the proceedings), or

(b)a party to the proceedings would be required to make such a disclosure were it not for one or more of the following-

(i) the possibility of a claim for public interest immunity in relation to the material,

(ii)the fact that there would be no requirement to disclose if the party chose not to rely on the material,

(iii)section 17(1) of the Regulation of Investigatory Powers Act 2000 (exclusion for intercept material),

(iv)any other enactment that would prevent the party from disclosing the material but would not do so if the proceedings were proceedings in relation to which there was a declaration under this section.

The second condition is that it is in the interests of the fair and effective administration of justice in the proceedings to make a declaration.

Section 8 gave more detailed explanation as to determination by court of application in section 6 proceedings. It explains what CMP requires, specifically that the material cannot be disclosed other than to the court, any person appointed as a special advocate, and where the Secretary of

\footnotetext{
${ }^{58}$ Above $\mathrm{n} 4$, Section 6(1) and Section 6 (2).
} 
State is not the relevant person but is a party to the proceedings, the Secretary of State. ${ }^{59}$ The closed material is admissible and "the court is required to give permission for material not to be disclosed if $i t$ considers that the disclosure of the material would be damaging to the interests of national security" ${ }^{60}$. A summary of the closed material can be given by the relevant person but the court is required to ensure that such a summary does not contain material the disclosure of which would be damaging to the interests of national security. ${ }^{61}$ If the court considers that the material or anything that is required to be summarised might adversely affect the relevant person's case or support the case of another party to the proceedings, then it must be authorised to direct that the relevant person not to rely on such points in that person's case, or in any other case, the court has to ensure that the relevant person does not rely on the material or on that which is required to be summarised. ${ }^{62}$

It is interesting to note that, under Section 6 of JSA, the wording of this provision seems to give the court space to authorise CMP, provided the two conditions have been met. However, Section 8 gives specific directions to the court as it is the court's responsibility to authorise CMP if a matter of national security involved.

Section 6(4)(b)(i) clearly outlines the government's intend of using CMP to substitute PII in the civil proceedings, in the circumstance that the case is in the interests of the fair and effective administration of justice. Therefore, this provision can be read as a declaration that the court should permit the application of using CMP, even if PII is applicable, however, this authorisation must be made in the interests of the fair and effective administration of justice. Then, so far, it seems the court still has the discretion of determining whether applying CMP in a case can satisfy the interests of fair and effective administration of justice. However, the question is how to measure these two sometimes opposing factors?

As the appellant in $\mathrm{Al}$ Rawi stated, replacing PII with CMP can achieve efficient administration, as the closed material is still admissible in CMP while going through the closed material under PII would cost a lot of resources and time. However, as the majority of the law Lords noticed, withholding evidence from an effected person is indeed in conflict with natural justice and procedure justice. Would a claim of efficiency be sufficient to offset the fairness requirement? It is possible for the government to argue that using special advocate system can help to achieve the fair administration claim as there would be a third, security-cleared, impartial person to assist the relevant person to look at the closed material, but the weakness in this case, is that again there are disadvantages in the special advocates system that, even if they use all their effort to look at the closed material, afterwards they are not allowed to communicate with the relevant party, nor their solicitors, letting alone to cross-examine witnesses or summon witnesses. Moreover, this requirement also departed from the government's justification of applying CMP

\footnotetext{
${ }^{59}$ Ibid, Section 8 (1) (a).

${ }^{60}$ Ibid, Section 8(1)(c).

${ }^{61}$ Ibid, Section 8(1)(d)(e).

${ }^{62} \mathrm{Ibid}$, Section 8(3).
} 
in $\mathrm{Al} \mathrm{rawi}$, ie the accountability and fairness. However, it is true that if the government required the court to authorise CMP on these grounds, which the court would have to examine the accountability and fairness first, then it probably will receive the rejection on the grounds the Supreme Court has given in Al Rawi.

Where a declaration is made, Section 8(1)(c) further requires the court to authorise CMP if it considers disclosing certain material would be damaging to the interests of national security. Based on the wording, the court would still have discretion in deciding whether the disclosure of certain material would be damaging to the interests of national security. However, this provision would enable the government so easily to use national security as a shield to avoid vetting from the relevant party, and the court, as it is such a broad term. Therefore, once a declaration is made by the court under Section 6 , the court must comply with section 8 .

It is also interesting to put the "core irreducible minimum" principle mentioned in Article 6 of ECHR, as well in $A F$ and $M B$ together when reading JSA. It is true that this principle was applied previously in the control order cases, however, the question is - is it possible for the court to refuse to grant permission of application of using CMP in the civil proceedings based on the relevant party must be informed of the allegations against him to give effective instructions to the special advocate? This paper holds the negative view as noted in Tariq, the majority of the Supreme Court noted there's a main difference between this case and $A F$, which can be summarised as $A F$ was a case where the relevant party was put under the criminal proceeding and that the liberty were severely endangered or even damaged; while Tariq was a case to challenge the English Law's justification in relation to the European Law and ECHR, and that compared to $A F$, the individual was not facing criminal proceedings nor his liberty right being severely restricted. The Court also noted that in the cases like Tariq, there are actual needs for the court to apply CMP.

While taking another look further at $A l$ Rawi, where the reluctance expressed by the Court was mainly the unwillingness of changing the rule of law-which as Lord Dyson noticed that the PII process is not perfect, yet it is adequate enough to deal with civil proceedings. ${ }^{63}$ As noted above, under PII the court has discretion to balance the public interest of withholding the evidence and disclosing the close material. While according to the rules for the court under JSA, the mere discretion for the court are the determination of fair and effective administration of justice, and further on the determination of whether disclosing material would damage the national security. Where the court does not have the "need" to exercise the Wiley balance, it was suggested that the British government was avoiding the possibility of repeat of the Binyam Mohamed ${ }^{64}$ case. In Binyam Mohamed, CMP was used in judicial review proceedings with the consent of the parties, while unlike in the statuary contexts in which CMP is used, PII proceeding, including the Wiley balance was applied, based on which the Court of Appeal decided to disclose information that

\footnotetext{
${ }^{63}$ Above $\mathrm{n} 6$ at 49.

${ }^{64}$ Binyam Mohamed $v$ Secretary of State [2011] QB 218.
} 
revealed the United Kingdom's officials were much well aware of the mistreatment of Binyam Mohamed while he was detained in Pakistan, based on the report supplied to them by the CIA.

An amendment to JSA that would have introduced the Wiley Balance was defeated in the House of Commons, just as it had been in the House of Lords. The reason given by the government was that the Wiley balance simply had no relevance in the context of CMP because there is no question of damage to the interests of justice by material being excluded from the proceedings altogether, which is somehow ironic judged by what happened after the Court decided to disclose the secret evidence based on PII in the Binyam Mohammed case.

However, taking a step back, if without JSA, and the Al Rawi case was not in a conflict with the Court's power in changing the common law, would the House of Lords agree the government's application of using CMP in the civil proceedings? It can be noticed in Tariq that the judgment given by the Supreme Court would likely cause uncertainty that judged by the degree of the rights of liberty were damaged, it is not likely for the court to apply CMP in the general civil case. While in this case, issuing CMP by the statutory power can simply be viewed as a clarification by the government to extend CMP to a broader regime.

As the concerns raised of JSA showed the government's desire of controlling over its secret evidence in the civil proceedings, there are certain points must be drawn out as the "light" of practicing CMP in the civil proceedings.

\section{$V$ Conclusion-Drawing out the "Light"}

As Lord Hoffman noted in $A F$, when deciding whether CMP is applicable, sometimes it is essential to look at the subject matter, ie the secret material, that whether withholding it would really affect the interests of the individual. As many scholars and judges have criticised CMP of damaging natural justice and open justice, they did not consider one circumstance where the secret material is in favour of the individual. That is to say, if exercising PII in the cases where the evidence is in support for the individuals, based on the public interest the evidence should be disclosed and inadmissible, while under CMP, the evidence can still be seen by the court and special advocates and despite being withheld. The court can still be able to rely on such evidence to decide potentially in favour of the individual. ${ }^{65}$

Also, for cases like Tariq, where as Lord Hope noticed that none of the alternatives were satisfactory. In this case, whether he court should proceed under CMP, otherwise the case should not be tried at all.

\footnotetext{
${ }^{65}$ Thanks to Franziska Liebelt for contributing this point.
} 
Further, the government brought forward an additional power for the court to revoke CMP. As Section 7 (2) states, "the court must keep the declaration under review, and may at any time revoke it if it considers that the declaration is no longer in the interests of the fair and effective administration of justice in the proceedings". Therefore, the fair and effective administration of justice is the key of the court to trigger CMP, as well as to terminate such a procedure.

The government also bowed to pressure to insert clauses requiring information about the use of CMP to be made public and for a review the operation of the system. For example, Section 12 of JSA required the Secretary of State to report on the use of CMP every twelve months, including the number of cases where it has been used and on the application of which party. ${ }^{66}$ Section 13 of JSA requires the Secretary of State to appoint a person to review the operation of the provision relating to CMP after five years. ${ }^{67}$ These provisions somehow enhanced a degree of transparency in the court operating cases under CMP.

It was said that when the United Kingdom first borrowed CMP to its own legal system, it was ill informed by thinking that operating CMP in the United Kingdom was with international approval, as the Court of Al Nashif v Bulgaria noticed,

Without expressing in the present context an opinion on the conformity of the above system [the special advocate] with the Convention, the Court notes that, as in the case of Chahal cited above, there are means which can be employed which both accommodate legitimate national security concerns and yet accord the individual a substantial measure of procedural justice. ${ }^{6}$

Yet, after the government issuing JSA, the criticism comes from across boundaries based on CMP violated procedural fairness as well as ECHR. While the issue is, as noted in $A F$, it is up to the state's sovereignty power to enact legislation which is incompatible with one or more convention rights. It can also be noticed from Tariq that procedural fairness does not seem to be a quite persuasive arguing point. Therefore, parliament enacting JSA to introduce CMP into the civil proceedings is a now a fixed point. Based on the "light" this paper draw above, and the intense situation happed to the United States after WikiLeaks incident, it is somehow understandable for the United Kingdom to adopt certain means in order to protect its national security as well as its diplomatic relationships with other countries. In relation to the natural defect of CMP, this paper would like draw few suggestions:

\footnotetext{
${ }^{66}$ Above $\mathrm{n} 4$ at Section 12.

${ }^{67}$ Above $\mathrm{n} 4$ at Section 13.

${ }^{68}$ Al Nashif v Bulgaria [2002] ECHR 497.
} 
First, as can be seen from many of the criticism about CMP is that one flaw of the special advocate system, in which the relevant person cannot communicate with the special advocate, or give instructions, and that the special advocate works all by itself without any support. It was suggested by nine special advocates,

...the principal requirement for a special advocate in proceedings before SIAC is the ability to absorb and analyse information that may be in voluminous documents and to cross-examine effectively on the basis of this. Such abilities are not confided to public law practitioners. While public law issues do sometimes arise in relation to closed material, the nature of the work may also require skills which those such as criminal lawyers or those with experience of handling witnesses in civil cases, would be equally if not better qualified to perform. ${ }^{69}$

The Lord Chancellor also accepted criticism about the insufficient number of special advocates and stated in favour of the relevant person should ultimately be able to choose the special advocate on the list ${ }^{70}$.

Second, in response to the provisions of summarising closed evidence under Section 8(3) of JSA, this paper suggests that the relevant person should not be forbidden of using the summarisation of relevant material or information. Conversely, the relevant person should be granted right to use the summarisation so that the individual can be able to make its own proper defence and know about the direction the case is leading to, which, is in compliance with procedural justice.

Given the statutory authorisation of the court applying CMP in the civil proceedings, it should also be interesting to see how would JSA influence the Terrorism Prevention and Investigation Measures regimes. However, it ultimately depends on how would the court interpret JSA and decide to use their new statutory jurisdiction to scrutinise the conduct of the British government.

\footnotetext{
${ }^{69}$ Above $\mathrm{n} 10$ at 29.
}

${ }^{70}$ Ibid at 29-30. 


\section{Bibliography}

A Cases

Al Rawi and Others $v$ Security Service and Others [2009]EWHC2959 (QB)

Al Rawi and Others v Security Service and Others [2010] EWCACiv 482.

Al Rawi v The Security Service and others [2011] UKSC 34.

$A$ and other $v$ United Kingdom Application No 3455/05 [GC].

Al Nashif v Bulgaria [2002] ECHR 497.

Binyam Mohamed v Secretary of State [2011] QB 218.

$R v$ Chief Constable of West Midlands, Ex $p$ Wiley [1995] 1 AC 274.

Secretary of State for the Home Department $v$ AF and other and one other action [2008] EWCA Civ 1148; [2009]UKHL 28.

Secretary of State for the Home Department v MB [2007] UKHL 46

Chahal v United Kingdom (1996) 23 EHRR at [130]-[131].

Home Office v Tariq [2011] UKSC 34.

B Legislation

Counter-Terrorism Act 2008 (UK).

Employment Tribunals Act 1996 (UK).

Justice and Security Act 2013. (UK)

Prevention of Terrorism Act 2005 (UK).

Special Immigration Appeals Commission Act 1997 (UK).

Terrorist Asset-Freezing Act 2010 (UK).

C Books and Chapters in Books 
Clive Walker Terrorism and the Law (Oxford, Oxford, 2011).

Denver Nicks Private: Bradley Manning, WikiLeaks, and the Biggest Exposure of Official Secrets in American History (Chicago Review Press, Chicago, 2012).

Hodge M Malek (ed) Phipson on Evidence (17th ed, Sweet \& Maxwell, London, 2010).

Jonathan Auburn, Jonathan Moffett and Andrew Sharland Judicial Review: Principles and Procedure (Oxford University Press, Oxford, 2013).

Kent Roach "Must We Trade Rights for Security? The Choice Between Smart, Harsh, or Proportionate Security Strategies in Canada and Britain" in David Dyzenhaus (ed) Civil Rights and Security (Ashgate, Surrey, 2009) 259.

Kent Roach "Secret Evidence and Its Alternatives" in Aniceto Masferrer (ed) Post 9/11 and the State of Permanent Legal Emergency: Security and Human Rights in Counter Terrorism (Springer, London, 2012).

Kent Roach "The Eroding Distinction between and Intelligence and Evidence in terrorism investigations" in Nicola McGarrity, Andrew Lynch and George Williams (ed) CounterTerrorism and Beyond: The Culture of Law and Justice after 9/11 (Routledge, USA, 2010).

\section{Journal Articles}

Adam Tomkins "National Security and the Due Process of Law" (2011) 64 CLP 1.

Aileen Kavanagh "Special Advocates, Control Orders and the Right to a Fair Trial” (2010) 73 The Modern Law Review 824.

David Jenkins "There and Back Again: The Strange Journey of Special Advocated and Comparative Law Methodology” (2011) 42 Columbia Human Rights Law Review 279

John Ip "Al Rawi, Tariq, and the Future of Closed Material Procedures and Special Advocates" (2012) 75 The Modern Law Review 606.

M Chamberlain "Update on Procedural Fairness in Closed Proceedings" (2009) CJQ 448 at 450.

Tom Hickman 'Turning out the lights? The Justice and Security Act 2013' (11th June 2013) UK's Constitutional Law Blog <http://ukconstitutionallaw.org> .

E Reports 
House of Commons Constitutional Affairs Committee The operation of the Special

Immigration Appeals Commission (SIAC) and the use of Special Advocates (22 March 2005) at 19 [46], available at <www.publiction.parliament.uk>.

F Internet Materials

$\mathrm{BBC}<$ www.bbc.co.uk $>$.

WikiLeaks $<$ Wikileaks.org $>$.

$<$ www.justice.gov.uk>. 